\title{
Policy Implementation of Main Naval Base VIII Manado in Handling Transnational Crimes in the North Sulawesi Border
}

\author{
Dian Handayani, ${ }^{* 1}$ Wavin Nuha Kuntanaka, ${ }^{1}$ Abdul Rahman ${ }^{2}$ \\ ${ }^{1}$ Master Program of Defense Management, Faculty of Defense Management, \\ Indonesia Defense University, Indonesia \\ ${ }^{2}$ Master Program of Asymmetric Warfare, Faculty of Defense Strategy, \\ Indonesia Defense University, Indonesia
}

DOI: https://doi.org/10.14710/jmsni.v4i1.7815

\begin{abstract}
This study aims to identify the policy of Main Naval Base VIII (Lantamal VIII) Manado to handle transnational crimes in the Manado sea border, North Sulawesi. It is implemented in order to support Indonesia's maritime security which contains communication, resources, disposition, and bureaucratic structure. This study uses a qualitative approach with a case study. Data collection using interviews and documentation while examining the data's validity using triangulation. The argument of this study is the communication made by Lantamal VIII Manado which represents the relation of Indonesia and the Philippines, while coordination

Received:

May 15, 2020

Reviewed:

June 11, 2020

Accepted:

June 12, 2020

${ }^{*}$ Corresponding Author:

dianhandayanidoel@gmail.com between the competent agencies in the waters of North Sulawesi requires good synergy. Nevertheless, there are several problems encountered by Lantamal VIII Manado, namely the lack of personnel and defence equipment. The disposition aspect has been going well according to the command mechanism. In addition, from the bureaucratic structure, Lantamal VIII Manado has a clear division of regional work.
\end{abstract}

Keywords: Policy Implementation; Transnational Crimes; Main Naval Base.

\section{Introduction}

Indonesia is one of the largest archipelagic states in the world, based on data derived from the Coordinating Ministry for Maritime Affairs and Investment (Kemenkomarves), in December 2019 the validated and verified islands reached 17,491. Aside from being an archipelago country, Indonesia is also notable as a maritime country with a composition of $2 / 3$ of its territory is the ocean. The strategic position of Indonesia's territory is also strengthened by cross-world position which connects the main international shipping lines. Based on national interests and global and regional geopolitics point of view, this condition is certainly a challenge as well as a threat to national defense.

Indonesia's sea area which reaches 5.9 million $\mathrm{km}^{2}$ is $2 / 3$ of the total waters of Southeast Asia as well as being an international shipping lane connecting the Indian Ocean and the Pacific Ocean and the waters in northern part of Indonesia (Arifin, Ras, and Siswoyo 2018). Geographically, the territorial waters of Indonesia that intersect with other countries become an early detection for the Indonesian government in counteracting various potential threats from neighboring countries, both military and non-military. For this reason, defense forces in the borders of Indonesian territorial waters must be a major concern of the government.

According to Octavian (2014) by using a sociological perspective, Indonesian waters has a huge potential, because the sea becomes a meeting point for the interests of various parties as a result of structural constraints on land. The sea become a space to realize their group interests, eventually this condition will lead to competition in the sea. 
Manado is the capital city of North Sulawesi Province. This city has twelve outer islands bordering directly with other countries. The outer islands such as Miangas Island, Marampit Island, Marore Island, Karatung Island, Kakorotan Island, Intata Island, Mangupun Island, Malo Pulau, and other outer islands. From the outer islands, there are only three outer islands which are guarded by the Outer Islands' Security Task Force [Satuan Tugas Pengamanan Pulau Terluar], those three islands namely Miangas Island, Marore Island, and Marampit Island.

Various problems in the outer border region of North Sulawesi Province pose a threat to national defense. Therefore, the government needs to pay attention to problems in the border region of North Sulawesi, especially in the fields of infrastructure, food sovereignty, economic resilience of society, availability of health facilities and infrastructure, equitable distribution of education in the border, and management of natural resource products both marine and agricultural products as the main sources of community livelihoods (Saha 2016).

Border disputes in Manado waters have potentially cause the tension and conflict with neighboring countries, especially Malaysia and Philippines. These two countries constitute as prone areas to transnational crime. In accordance with the 2002 World Program for Implementing the Plan of Action for Combat Transnational Crime, in Southeast Asia there are several types of transnational crime such as drug trafficking, human trafficking, sea-piracy, weapons smuggling, money laundering, terrorism, economic crime international and cyber-crime (Ministry of Defense of the Republic of Indonesia 2015, 19).

The previous studies emphasize on how transnational crime occured in the Sulawesi border. For instance, a study by Febrica (2014) that focuses on how the cooperation between Indonesia and the Philippines in combatting transnational crime. Some attempts also have been undertaken to encounter those problems. These two countries had established a regional security patrol agreement in the territories in 1997. One of the implementations was a joint military training exercise, joint patrols in the border region, and information exchange. With this objective condition, it requires the role of the Navy in executing the implementation of the cooperation.

Transnational crime in the border region in North Sulawesi and southern Philippines waters also driven by terrorism affiliation (Amarulla 2017), namely the Abu Sayyaf Group (ASG). The recent maritime violence is piracy of Indonesian ships in the Sulawesi-Sulu Sea, bordering the Philippines and Malaysia. Various incidents of hijacking and hostage ships occurred from March to June 2016 in the border areas. The group hijacked some ships, including TB Brahma 12, the barge BG Anand 12, the barge BG Christi, and TB Henri (Arifin, Ras, and Siswoyo 2018, 43). It involves Association of Southeast Asian Nations (ASEAN) countries which shows a trend of increasing number of cases and modification of cases. In the context of expanding influence, the Abu Sayyaf has built weapons and power centers in the Sulu waters (Singh 2018, 8).

Moreover, the existence of the North Sulawesi government program in the context of the internationalization of Manado tourism and other potential resulted in an increase in the amount of traffic of people or goods from abroad to Manado. Direct flight to Sam Ratulangi Airport from several countries such as Singapore, Guangzhou, China and several other countries increasing the escalation of transnational crime.

Seeing the challenges and threats that exist, the sea route has more potential and is prone to crime. This is due to the lack of supervision system of the Navy, the Indonesian Maritime Security Agency (Bakamla), the Water Police, and other agencies. This condition is proven by the large number of transnational crime cases that have crossed the waters of North Sulawesi. Therefore, the government responsibility is to build and prepare a reliable maritime defense system in the border area of Manado. It is necessary to make a deterrent effect to neighbouring countries.

The Naval Base (Lantamal) VIII which located in Manado is a territorial unit that has a working area from Toli-toli waters in Central Sulawesi, northern and southern of Gorontalo to Talaud waters bordering the Philippines. The duties of the Lantamal are to provide logistical and administrative support to the operational units of the Navy, establish security patrols, and foster national maritime potential (Okezone, 21 March, 2018). Based on these duties, it can be concluded that Lantamal VIII Manado has a very strategic role in handling various transnational crimes that occur in Manado waters. 
According to Keliat (2009), a study on maritime security is still neglected, specifically on ontological definition and limitations related to maritime security. Therefore, this present article examines a maritime security issues in North Sulawesi border areas, especially in Manado. It is necessary to portray how Lantamal VIII Manado policy in handling transnational crimes. In addition, the root problems and obstacles faced by Lantamal VIII Manado also explained in this article.

\section{Method}

This study is a qualitative method with a case study. Based on its purpose, case study research can be divided into three types, namely explanatory, exploratory, and descriptive case studies. Explanatory case studies are used when researchers will explain a series of events that are causal (causality) (Creswell, 2015: 207)

The study was conducted in Lantamal VIII Manado, North Sulawesi Province, which subsequently became the research subject. The data type uses the explanation given by the informant from Lantamal VIII Manado as primary data and documentation method as secondary data. Furthermore, data analysis techniques include data collection, data reduction, data display, and conclusion drawing. As for testing the validity of the data using triangulation techniques.

\section{The Threat of Transnational Crime in the Waters of Manado, North Sulawesi}

The geographical location of Manado bordering with neighboring countries, especially the southern Philippines and Malaysia, makes the waters in Manado vulnerable to transnational crime. It is become increasingly challenging along with the transformation on technological and information developments. Lantamal VIII Manado has published a map of transnational crime vulnerability spread in Manado Waters. There are factual and potential threats including illegal fishing, illegal weapon, drugs trafficking, illegal imigrant, smuggling of illegal goods, dangerous fishing. Meanwhile, potential threat such as maritime terorism, foreign warships that stopped in Manado, violation of shipping regulations. Furthermore, transnational crime in Manado dominated by illegal fishing and dangerous fishing with illegal equipment.

\section{Factual Threats}

According to the informant that the level of transnational crime in the waters of Manado is still in the category can be handled well by Lantamal VIII Manado along with other authorized institutions. Transnational crimes that dominate in Manado waters are illegal fishing, smuggling of goods, drugs through the rat route, and smuggling of foreign workers who enter the Manado area and maritime violence in the form of terrorism and ship hijacking (Interview with Johanes Djanarko Wibowo on 24 February 2020).

Cases of smuggling of goods themselves are usually dominated by smuggling of illegal goods such as weapons, drugs, and daily necessities. In terms of combating smuggling of goods of daily necessities, Lantamal VIII Manado along with other agencies continue to work in terms of supervision of the entry and exit flow of goods. It cannot be denied that the fulfillment of daily necessities through smuggling activities is an economic motive for the people of North Sulawesi. This can occur because access to obtain daily necessities is easier from the Philippines compared to the main cities in North Sulawesi.

Apart from easy access to the Philippine region, the communities in Manado waters and the Philippines have a very tight relationship. Therefore, the government through related institutions must pay attention to customary laws which are entrenched in the community. Furthermore, for the smuggling of weapons and drugs, Lantamal VIII Manado continues to synergize with all stakeholders in terms of prevention. The principal motive in such criminal action were driven by economic gain. In this case, seas became a medium in transporting weapons and drugs. Compared to land basedtransportation, seas considered more efficient and low cost.

Smuggling of foreign workers is a classic issue encountered by Lantamal VIII Manado. Indeed, a mutual relationship between two communities in Indonesia and Philippines made a high opportunity for the intensity of smuggling of foreign workers. In addition to smuggling of daily 
necessities, illegal weapons, drugs, and foreign labor. There are several illegal fishing activities were mostly carried out by Filipino fishermen in North Sulawesi waters. Finally, the actual threat found in the waters of North Sulawesi is the existence of maritime violence in the form terrorism acts and piracy of Indonesian fishing vessels. The threat was initiated by the affiliation of ASG, which repeatedly abducted crew members. According to the informant, the ASG group continuously establish a wider network and undertake criminal actions (Interview with Johanes Djanarko Wibowo on 24 February 2020).

\section{Potential Threats}

To realize the defense posture, threat perception is needed in order to make a deterrent effect. In this case, threat perception is analyzed based on the current situation in of Manado waters. This sustainability becomes a parameter for Lantamal VIII Manado in formulating various strategic plans. According to Wibowo, Manado is one of the cities with a very high tolerance level so that the cases of radicalization or terrorism are very small compared to other cities in Indonesia. But, looking at the mobility of incoming and outgoing citizens such as the Philippines to the North Sulawesi or vice versa posed a sovereignty issue. Potential threats from the high mobility of citizens in North Sulawesi also prompt a mobility of terrorists around the southern Philippines and North Sulawesi. Eventually, it effected on the internationalization of Manado and the instability at the North Sulawesi-Southern Philippines border (Interview with Johanes Djanarko Wibowo on 24 February 2020).

\section{The Massive Movement of Terrorist Groups in the Border Region of the Southern Philippines and North Sulawesi}

There are several armed groups in the southern Philippines including the Moro National Liberation Front (MNLF) and the Moro Islamic Liberation Front (MILF), each based in a mountainous area in the hamlet of Kawayan, Barangay Kepinggan, and Barangay Balibo. Not surprisingly, in the southern Philippines there are numerous armed conflicts and acts of terrorism which have implications for the security system in North Sulawesi as a border region.

Based on the hypothesis from the North Sulawesi Regional Police, suspected terrorists who attacked Bali and Jakarta have frequently crossed into Indonesian territory from Balut-Sarangani Islands or General Santos City in the southern Philippines, then transit in Talaud region, especially Miangas Island and Marore Island. After a series of terrorism acts both in Jakarta and Bali, it was discovered that there were a number of suspected people escaping from Sangihe and Talaud. The movement of the suspected terrorists was allegedly utilizing the provided facilities for local residents to conduct family visit activities, both in the southern Philippines and North Sulawesi. Therefore, the Philippine government itself has taken anticipatory steps by increasing the requirements for completing documents for Filipino-Indonesian border crossers. The mobility of suspected terrorists or suspected people who has an affiliation with militant groups in the southern Philippines certainly raises the potential threat of terrorism in Indonesia.

The main basis of ASG was located around Jolo Island and Basilan in the southern Philippines. Several names are pinned to this group related to various acts of violence. Terrorist groups, insurgents, pirates, sea bandits are designations attached to the ASG group. This organization was founded in 1990 by Abdurajak Abu Bakar Janjalani after his return from Afghanistan for the purpose of forming an Islamic state in the southern Philippines region.

In line with that, in a study by Sahrasad et al (2018) stated that Mindanao is one of the regions in Southeast Asia which has long been the basis of world-class terrorism. ASG is the well-known terrorist group in southern Philippines which has a range of networkings. This fact makes the Abu Sayyaf as a source of tension and comflict, especially in the southern Philippines and in Southeast Asia in general. Moreover, the maritime area between Sulawesi and Mindanao seems to be a key logistical corridor, particularly for the extremist groups, for instance, Jemaah Islamiyah (JI) (Rabasa 2007, 111).

Various Abu Sayyaf Group actions often occur in the territorial waters of North Sulawesi. To gain recognition and steal the attention of the international community, ASG began to carry out acts of violence such as bombings, killings, and kidnappings. In 1969, there was a conflict due to political 
tension and attacks between the Philippine government and Muslim armed groups in Moro. There are 60 Filipino Muslims dead during the operation (Abuza, 2014). In 2000 ASG consolidated and led larger attacks including the Super Ferry 14 bombing in 2014 which resulted in 116 fatalities. Furthermore, in 2014, ASG carried out a deadly attack against 21 Filipino Muslims.

In July 2016, ASG was allegedly initiated several actions in Sabah (Malaysia) territory- TawiTawi (southern part of the Philippines), the group was targeting the tug TB Brahma 12 and the barge BG Anand 12, the action was occured in Sulu, southern Philippines. 10 crew members of Indonesian ships were taken hostage. The second incident occurred on April 15, 2017 in Tawi-Tawi waters, southern Philippines, bordering east coast of Sabah, Malaysia. On a returning trip from Cebu, Philippines to Tarakan, North Kalimantan, the barge BG Christi and the tug TB Henri was hijacked by ASG. 10 crew members, 5 people escaped, 4 were kidnapped and 1 person was shot by the perpetrators. The two ships were finally rescued to the Lahat Datu Port of Malaysia. The third incident was also led by ASG on June 20, 2017, the group attacked the TB Charles 001 tugboat and the BG Robby 152 barge owned by PT. The Rusianto Bersaudara in the Sulu Sea, Southwest of the Philippines on a voyage from Tagoloan, Misamis Oriental, Mindanao, to Samarinda, East Kalimantan. From 13 crew members, 7 people were taken hostage and 6 others were released to continue the journey (Arifin, Ras, and Siswoyo 2018).

The rapid development of technology and information as a result of the industrial revolution 4.0 is both a challenge and a threat to national security and defense. The implications of the development of technology and information resulted in the internationalization of the city of Manado which made the tourism and fisheries sector a bargaining power of the city of Manado. One indicator of internationalization is easy open access. One of them is the opening of direct flight at Sam Ratulangi Airport from various cities in the world such as Singapore and China.

The impact of internationalization on the tourism sector is an increase in the number of foreign tourists entering Manado. In addition to the positive impacts of increasing foreign exchange or regional income, it also brought about negative effects including degradation of local wisdom values, increased human trafficking activities, drug smuggling, prostitution, and environmental exploitation as well as inequality due to local people not being employed in sectors formally from tourism (McCool 2016, 20). Negative impacts that may occur must be anticipated with strategies that can balance the internationalization process of Manado with the development of sustainable tourism, which promotes the social interests of the local community (socially acceptable), in line with environmental sustainability, but still economically profitable.

\section{The "Pisang" Dynamics (the Philippines-Sangihe) at the Border as a Potential Threat}

The "Pisang" is an abbreviation of Pilipina (local name for the Philippines) and Sangihe. The term "Pisang" is usually to describe Sangihe women who are married to Filipino men which then living in the Philippines. Based on official data, it has reached around 7,000 to 8,000 Indonesian citizens living in the Philippines which are categorized as Undocumented Citizens because they do not have immigration documents that prove their citizenship. Residents residing in the Philippines and claiming of having Indonesian descent will be recorded at the Consulate General in Davao City and not entitled to have a Filipino identity card, only cross-border identity cards will be given.

In such circumstances, citizens with the "Pisang" category are vulnerable in political and population policies because of their stateless position. This certainly can be used politically or economically. This existence and problem have become an agenda in the Indonesia-Philippines Joint Bilateral Commission, but the process of resolution requires a long time. The Philippine Immigration Bureau and the Indonesian Consulate General in Davao had conducted a survey to find out the wishes of the community towards three possible choices, namely: 1 . Naturalization: choosing to become a citizen of the Philippines 2. Repatriation: relocation to the territory of the Republic of Indonesia 3. Legalization: becoming an Indonesian citizen living in the Philippines.

This "Pisang" citizen mobilization certainly has several impacts on maritime security in the North Sulawesi region. One of them is the existence of illegal pathways used by "Pisang" fishermen to carry out fishing activities. It results in economic losses and exploitation of natural resources. On the other hand, the illegal entry of "Pisang" fishermen brings benefits, namely new knowledge and 
technology to local fishermen. In addition, the mobility of "Pisang" also has the potential to cause sentiment over the struggle for economic resources between "Pisang" and local residents.

Tahuna as the capital of the regency is bustling with the problem of unbroken cross-border issues, especially Filipino fishermen who are free to roam in Sangihe. Residents assume that they need to collect data on how many pumpboats, fusos, pamos operate in Sangihe waters and how many crew members are temporarily operating. Numerous pumpboats, fusos, pamo ownership Indonesian citizens or Filipino citizens which undertaken both legal and illegal actions. Another controversy is that arms smuggling is rife at the height of the Maluku, North Maluku and Poso conflicts. Then the trafficking of illegal drugs originating from the southern Philippines network was dismantled by the police with the arrest of drug dealers in Manado. Based on the results of Widodo's research (2018) on strategies to prevent the threat of insurrection in North Sulawesi explained that the mobility of "Pisang" as a threat is not real. However, the activities carried out by the "Pisang" community can lead to the potential for illegal activities such as weapons smuggling and illegal fishing.

\section{Policy Implementation of Lantamal VIII Manado in Handling Transnational Crimes in Manado Waters, North Sulawesi}

\section{Communication Aspects}

In dealing with various problems that have occurred and the possibility of potential threats on the North Sulawesi-Philippines waters border, Lantamal VIII Manado worked on diplomatic paths with the Philippines through agencies appointed by the Philippine government. The diplomatic effort as a soft power approach by Lantamal VIII is believed to be a solution for resolving border conflicts without causing military or non-military tensions between the Indonesian-Philippine governments. Therefore, a harmonious relationship between the two countries can be achieved.

Lantamal VIII personnel actively and cooperatively carried out diplomatic efforts through negotiations. A source of information describes that the Indonesia-Philippines negotiations have taken place six times over the past 3-4 months. Those were carried out interchangeably and routinely in response to the escalation of conflicts in border areas. Tension between Indonesia and the Philippines had once escalated when the Philippines claimed over Miangas Island but, through diplomacy, Indonesia has regained full rights over Miangas Island as an integral part of the territory of the Republic of Indonesia (NKRI).

In addition to the smoothly operational diplomatic efforts, handling cases at the border involving different agencies such as Bakamla, Polair, Customs, and so forth. It was also hampered by overlapping communication problems. For example, the arrest of Indonesian Navy violators was not fully followed up by the Directorate General of Customs under the excuse of administrative completeness. All these agencies show the lack of communication and synergy in handling a variety of cases ranging from the mechanism of arrest and delegation to punishment.

Misperception and overlapping rules can also be seen from communication between Lantamal VIII Manado and the local police. To overcome and anticipate this problem, the government needs to strive for specific regulations such as the ratification of the Bill on National Security as a regulatory reform to create a good communication pattern between the TNI and the Police.

\section{Resource Aspects}

To realize the defense posture can be seen from the aspect of resources owned by an agency. In this case the researcher will analyze the availability of defense equipment and personnel as the main factors to realize the strength of defense of Lantamal VIII Manado, specifically in handling transnational crimes in Manado-Philippines territories.

Lantamal VIII Manado still has a limited number of personnel. It has not reached one hundred percent $(100 \%)$ according to idealism in achieving defense forces. Based on documentation data, the strength of Lantamal VIII Manado has only reached 35\%. This condition is certainly have an impact on professionalism in carrying out basic duty and functions, both in structural and in position. Navy personnel must have a variety of skills and flexibility in carrying out different duties. In detail related to the limited resources of Lantamal VIII Manado personnel can be seen through the following figure. 
Furthermore, when observing from the aspect of the availability of defense equipment owned by Lantamal VIII Manado it still does not meet the standard of the defense equipment itself, both quantity and quality. Reviewing the threats escalation in the border areas of the Manado-Philippines waters, there is a need for attention from the central and regional government in terms of adequate budget allocation. The availability of adequate budget will certainly have implications for military spending, especially for the procurement or maintenance of defense equipment. $2 / 3$ of Indonesian areas is the territorial waters, ideally the military budget must be qualified by holding the principles of budget effectiveness and efficiency, especially in the field of defense equipment of the Navy,

Based on the results of the documentation that in supporting the defense forces in the Lantamal VIII Manado, the working area has the strength of defense equipment in the form of 2 units of the Naval Vessel of the Republic of Indonesia (Kapal Perang Republik Indonesia/KRI), 10 units of Navy Ships (Kapal Angkatan Laut/ KAL), 9 units of Maritime Security Patrol (Kapal Patroli Keamanan Laut/Patkamla), 7 units of sea riders, 3 combat boats, 1 speed, 11 inflatable boat units, and 4 lifeboats. The central and regional government as well as the Ministry of Defense must pay attention to the limitations and deficiencies of the defense equipment owned by Lantamal VIII Manado as the frontline in facing various potential threats in the border waters of Manado, North Sulawesi and the Philippines.

\section{Disposition Aspects}

According to Edwards $(1980,89)$, disposition is the attitude or nature of the executor of a policy that has been determined by the leader (decision maker). If the attitude is in accordance with the intentions and desires of the leadership. A policy will be implemented properly. Conversely, if the executive has a different view or perspective of the leadership of a policy, the policy implementation will be ineffective.

\section{Structural Aspects of Bureaucracy}

The bureaucratic structure also has a significant role in influencing the implementation of a policy, including the implementation of handling transnational crime. A good bureaucratic structure will certainly support the effectiveness of handling these crimes, and vice versa, a bad structure can actually be an obstacle and an obstacle. A clear bureaucratic structure in this case can be seen from the division of Lantamal VIII Manado working area. Lantamal VIII Manado oversees six Indonesian Navy bases which spread in North Sulawsi, Gorontalo, and Central Sulawesi. It covers approximately 234 islands in the province of North Sulawesi. In fact, there are still many uninhabited islands in the IndonesiaPhilippines border area.

In performing its duties in the border region, Lantamal VIII Manado still needs to develop its strength, including the plan to develop several Navy posts into Indonesian Navy Base Type C, and several Indonesian Navy bases Type C to Type B. In this context, we also see how changes in bureaucratic structure are closely related to efforts to develop the availability of resources. Upgrading institutional units will increase resource requirements.

\section{Root of the Problems and Obstacles}

Based on the analysis of researchers, various potential transnational crimes in Manado waters have four root problems. First, geographical condition, which is directly adjacent to the southern Philippiness, is a theat to the country which provides a loophole for transnational crime. Moreover, the outer islands of North Sulawesi are closer to the Philippines than the mainland of North Sulawesi.

Second, the lack of defense equipment owned by the Navy in the border area, it has not have a daunting effect on transnational offenders. Third, a dependency of economic activities between communities in the outer islands of North Sulawesi and southern Philippines. The people of North Sulawesi find it easier to get daily necessities from the Philippines compared to the cities of North Sulawesi, which is arguably very far and requires time and money. This causes rampant cases of smuggling of goods, especially goods for daily necessities.

The last problem is among the economic sectors in Manado, the mainstay came from the fisheries and tourism sectors. During this time, the development of the fishing industry has been 
marked by illegal, unreported, and unregulated (IUU) fishing. Two patterns of fishing that the Ministry of Maritime Affairs and Fisheries categorizes as violating the law are transshipment and use of ex-foreign vessels. Indeed, many of the fishermen move illegally to other countries, especially the Philippines and Japan, through this method. However, it turns out that there are many fish processing factories in Manado that also use a similar mode. As a result, the war on fish theft policies promoted by the Ministry of Maritime Affairs and Fisheries has an impact on the domestic fishing industry in Manado. This problem needs to be resolved. In the midst of a weakening economic condition, the plan for internationalization is likely to worsen the real economy of society, thereby increasing the potential for crime, including transnational crime.

In carrying out the assignment Lantamal VIII Manado to deal with transnational crimes in Manado-Philippines waters, there are several obstacles, especially related to the limited of Human Resources (HR). As explained in the previous discussion, aspects of the strength and personnel of Manado's Lantamal VIII defense equipment are still limited. The potential of human resources in Lantamal VIII Manado still needs to be improved, especially in the strength of personnel. In addition, lack of facilities and infrastructure in Lantamal VIII Manado also becomes an obstacle in dealing with transnational crime in North Sulawesi. Therefore, the output is less than optimal. The strength of defense equipment that has not been optimal is also a problem in carrying out the duties and functions of Lantamal VIII Manado. Based on these obstacles, the budget effectiveness and efficiency scheme must be applied in Lantamal VIII Manado.

\section{Conclusion}

Factual threats of transnational crime at the border areas between Indonesia and the Philippines can be handled by the role of Lantamal VIII Manado along with the involvement of other stakeholders. The potential for future threats is very large due to the difficulty in accessing the North Sulawesi border due to its geographical conditions, the lack of economic equality of communities in the outer islands of North Sulawesi, and the instability in the southern part of the Philippines region which has the potential to cause maritime violence in the outer islands of North Sulawesi.

Furthermore, the implementation of policies conducted by Lantamal VIII Manado can be seen from four aspects, including communication, resources, disposition, and bureaucratic structure. In terms of bilateral diplomacy, the communication made by Lantamal VIII Manado have been going well. Nevertheless, the lack of communication and synergy between the competent agencies in handling transnational crime needed to be improved. In terms of resources, Lantamal VIII Manado is still not optimal due to the limited number of personnel and defense equipment in supporting maritime defense and security efforts. In the aspect of disposition, the field has been going well according to the command or order of the leader. However, the overlapping regulations oftentimes brought about misperceptions. Meanwhile, from the aspect of bureaucratic structure, Lantamal VIII Manado has a clear division of regional work.

\section{References}

Abuza, Zachary. 2014. Counter-Terrorism: The Return of the Abu Sayyaf. Pennsylvania: Strategic Studies Institute.

Arifin, Saleh, Abdul Rivai Ras, and Mardi Siswoyo. 2018. "Pencegahan Aksi Kekerasan Maritim oleh Kelompok Abu Sayyaf di Laut Sulawesi-Sulu Dalam Kerangka Keamanan Maritim (Studi Kasus Kapal Tunda TB Brahma 12-Kapal Tongkang BG Anand 12).” Jurnal Keamanan Maritim 4 (2): 39-66.

Creswell, J. W. 2015. Penelitian Kualitatif dan Desain Riset: Memilih Di antara Lima Pendekatan. Yogyakarta: Pustaka Pelajar.

Edwards, George C. 1980. Implementing Public Policy. Washington DC: Congressional Quarterly Press.

Febrica, Senia. 2014. "Securing the Sulu-Sulawesi Seas from Maritime Terrorisme: A Troublesome Cooperation?” Perspectives on Terrorism 8 (3): 64-83. https://www.jstor.org/stable/10.2307/ 26487539. 
Keliat, Makmur. 2009. “Keamanan Maritim dan Implikasi Kebijakannya bagi Indonesia." Jurnal Ilmu Sosial dan Ilmu Politik 13, no. 1: 111-129. https://doi.org/10.22146/jsp.10970.

McCool, Stephen F. 2016. Reframing Sustainable Tourism. New York: Springer.

Ministry of Defense of the Republic of Indonesia. 2015. "Indonesia Defense White Paper 2015".

Octavian, Amarulla and Bayu A. Yulianto. 2014. Budaya, Identitas dan Masalah Keamanan Maritim. Jakarta: Universitas Pertahanan Indonesia.

Octavian, Amarulla. 2017. "In Search of Peaceful Future of the Asia-Pacific Maritime World: Formulating the Role of Indonesian Navy." Journal of Maritime Studies and National Integration 1 (2), 118-127 DOI: https://doi.org/10.14710/jmsni.v1i2.1998

Rabasa, Angel. 2007. "Case Study: The Sulawesi-Mindanao Arc." In Ungoverned Territories: Understanding and Reducing Terrorism Risks, 111-46. RAND Corporation. www.jstor.org/stable/10.7249/mg561af.16.

Sabu, Subhan. "Tingkatkan Keamanan di Wilayah Perairan, Lantamal VIII Bangun Pos TNI AL". Okezone, 21 March 2018. https: //news.okezone.com/read /2018/03/21 /340 / 1875682/tingkatkan keamanan-di-wilayah-perairan-lantamal-viii-bangun-pos-tni al.

Saha, P. 2016. "Indonesia's Potential as a Maritime Power." Maritime Affairs: Journal of the National Maritime Foundation of India 12 (2), 28-41. DOI:10.1080/09733159.2016.1232951

Sahrasad, Herdi, Al Chaidar, M. Akmal, Saifullah Ali, Nanda Amalia, Dara Quthni Effida. 2018. "Maritime Terrorism Network: Threat and Security in Contemporary Southeast Asia." Jurnal Penelitian Sosial Keagamaan 26 (1): 115-146. http://dx.doi.org/10.21580/ws.26.1.2274.

Singh, Bilveer. 2018. "Crime-Terror Nexus in Southeast Asia: Case Study of the Abu Sayyaf Group." Counter Terrorist Trends and Analyses 10, no. 9: 6-10. ARF

Widodo, Pujo, Pujo Widodo, Mardi Siswoyo, Fauzia Gustarina Cempaka Timur. 2018. Strategi Penjagaan Perbatasan Laut: Indonesia dan Filipina Dalam Mencegah Ancaman Insurjensi di Sulawesi Utara. Jurnal Peperangan Asimetris 4 (2): 21-48.

\section{Informants}

Wibowo, Johanes Djanarko. 24 February 2020. Hall Building, Lantamal VIII Manado, Indonesia. Interview by Dian Handayani. 